\title{
Evaluation of the Apoptotic Effects of the Humic Acid Treatment on Chronic Myeloid Leukemia Cell Line K562
}

\author{
Pinar Mega Tiber' $\mathbb{D}^{\mathrm{D}}$, Tuğçe Balcı-Okcanoğlu² $\mathbb{D}$, Melike Karadeniz' $\mathbb{D}^{\mathrm{D}}$, Asli Aykaç ${ }^{3}$ (D) \\ 'Department of Biophysics, Marmara University Faculty of Medicine, İstanbul, Turkey \\ ${ }^{2}$ Department of Medical Biology, Near East University Vocational School of Health Sciences, Nicosia, Cyprus \\ ${ }^{3}$ Department of Biophysics, Near East University Faculty of Medicine, Nicosia, Cyprus
}

ORCID iDs of the authors: P.M.T. 0000-0003-0819-0702; T.B. 0000-0003-0613-765X; M.K. 0000-0002-6277-6918; A.A. 0000-0002-48855070.

\author{
Cite this article as: Tiber PM, Balcı-Okcanoğlu T, Karadeniz M, Aykaç A. Evaluation of the Apoptotic Effects of the Humic Acid \\ Treatment on Chronic Myeloid Leukemia Cell Line K562. Cyprus J Med Sci 202I; 6(2): I57-161.
}

\section{BACKGROUND/AIMS}

Humic acid (HA) formed by the decomposition of organic matter is a high-molecular-weight polymer. Humic-derived substances are potential drugs for human health, and their role in the prevention and treatment of diseases, like diabetes, antiviral, UV-B protective effect, cancer, and cardiovascular disease, is emphasized in various studies. It has antiulcerogenic, antitumor. Yang et al. demonstrated that $\mathrm{HA}$ exerts an antiproliferative effect and growth inhibition on HL-60 cells through the induction of apoptosis. A study showed that the antiulcer effect of Shilajit (HAs extracted from Shilajit) samples may be due to antimicrobial, anti-inflammatory, antianxiety, antioxidant, healing, and regenerative effects. The present study aimed to investigate the effects of HA on cultures of the chronic myeloid leukemia cell line in vitro.

\section{MATERIAL and METHODS}

We determined the apoptotic effect of HA in K562 cells by using various molecular methods. For cell viability, HA was tested in vitro against K562 cell lines using the MTT colorimetric process. Bax, bcl-2, casp-3, and casp-9 expressions were quantified by Western blot. Apoptosis analysis has been made with the Annexin- $V / P /$ method.

\section{RESULTS}

The $\mathrm{IC}_{50}$ values of $\mathrm{HA}$ were determined $100 \mu \mathrm{g} \mathrm{mL} \mathrm{L}^{-1}$ for the $\mathrm{K} 562$ cell line. HA has been shown to inhibit cell proliferation. As the bcl-2/ bax ratio decreased and increasing the levels of caspase- 3 and caspase-9, the cells underwent apoptosis.

\section{CONCLUSION}

As a result, HA showed the anticancer effect on leukemia cells. In the future, HA can be used as a chemopreventive agent in leukemia treatments.

Keywords: Anticancer treatment, caspase-3, caspase-9, bcl-2, bax

\section{INTRODUCTION}

Humic acid (HA) formed by the decomposition of organic matter is a high-molecular-weight polymer.,2 HA, which has cation exchange capacity, makes the soil fertile by increasing the mineral forming capacity of the plants. In the literature, studies are reporting that polyphenol, quinone, and polycarboxylic groups in the structure of humic substances impart antiulcerogenic, antitumor, and anti-inflammatory effects to the substance. ${ }^{3-5}$ Humic substances are used in traditional Chinese medicine because of their many pharmacological properties. ${ }^{2,6}$ The presence of studies emphasizing the role of humic substances in the prevention and treatment of wound healing, antiviral, cardiovascular diseases, osteoarthritis, cancer, and inflammation can be regarded as evidence emphasizing that humic substances are potential drugs for human health. ${ }^{7-10} \mathrm{HA}$, therefore, has the potential for medical use in cancer treatment.

Chronic myeloid leukemia (CML), a myeloproliferative disease identified by the increased and unregulated increase of myeloid cells in the bone marrow and accumulation of these cells in the blood. Although white cells work close to normal in CML patients, their numbers are higher than normal. As this numerical height continues to increase, leukemia 
begins to develop in parallel with this increase. Although there is a lack of data on the global incidence of $C M L$, which seems to have no relationship with race or ethnicity, which accounts for $15 \%$ of all leukemias worldwide, it is evident that more than 10,000 patients will be affected by CML each year, and this will cause significant global health burden."11, In addition to chemotherapy, some natural antitumor drugs, such as paclitaxel and camptothecin, are used in the treatment of $C M L$, which is a difficult malignant hematological disease to treat. ${ }^{13}$ Due to the side effects and drug resistance of the drugs used, there is a continuing need to develop effective natural antitumor drugs for the treatment of CML.

Recent research has shown that a wide variety of chemotherapeutic agents provide the initiation of apoptosis. Bcl-2 (inhibitor) and bax (activator) proteins from the family of the bcl-2 associated $X$ members of proteins have a crucial apoptosis function. The levels of protein inhibitors and activators play a key role in the apoptotic cycle. The improvement in the inhibitor-activator-protein ratio is informative regarding apoptosis regulation. ${ }^{14}$ Most anticancer drugs used by apoptosis to destroy some forms of tumor cells suggest that apoptosis often plays a function in the death of cancer cells caused by drugs.

Our objective in this research was to examine HA's anticancer activity in the K562 cell line and to identify possible cell death pathways that are impaired in vitro. Here, we demonstrate that HA keeps from proliferation and cause apoptosis in the human $\mathrm{CML}$ cell line K562 at approximately $100 \mu \mathrm{M}$ concentrations.

\section{MATERIAL and METHODS}

\section{Purification of HA}

HA (Sigma-Aldrich Co., Darmstadt, Germany) was acidified with a $\mathrm{pH}<2.0 \mathrm{HCl}$ solution after dissolution in $\mathrm{pH}>10 \mathrm{NaOH}$ solution. After half an hour of centrifugation at $3,000 \times g$ as described by Schnitzer's, ${ }^{15}$ the procedure was repeated three times to obtain the purest form of $\mathrm{HA}$ dissolved in $\mathrm{NaOH}$ solution. Prior to the

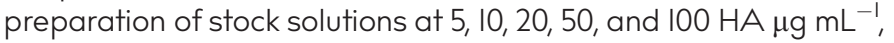
the powdered HA was dissolved with PBS ( $\mathrm{pH}=7.4)$.

\section{Cell Culture}

The K562 cells (ATCC: CCL-243) were cultured in RPMI 1640 medium (Biochrom, FGI2I5, Berlin, Germany), supplemented with $10 \%$ inactivated fetal bovine serum, $1 \%$ L-glutamine, and $1 \%$ penicillin-streptomycin (supplied from Capricorn Scientific, FBS-IIB, Ebsdorfergrund, Germany; EMD Millipore, K0282, Darmstadt, Germany; Biochrom, A22I3; respectively). The cell culture experiments were performed at $37^{\circ} \mathrm{C}$, physiological $\mathrm{pH}$, and in a $5 \% \mathrm{CO}_{2}$ humidified atmosphere. Our study was conducted according to the Helsinki Declaration.

\footnotetext{
Main Points

- Humic acid (HA) has anticancer activity on chronic myeloid leukemia cell line.

- HA helped decrease the bcl-2/bax ratio in K562 cell lines.

- HA helped increase the level of casp-9 in K562 cells.
}

\section{Cell Viability Assay}

Following 24 hours of incubation, proliferation and viability measurement of $\mathrm{K} 562$ cells against $\mathrm{HA}$ at a concentration of 5-100 $\mu \mathrm{g} \mathrm{mL}^{-1}$ was evaluated by the cell proliferation kit I (MTT) (Roche II46500700I). 96-well culture dishes were seeded with $\mathrm{K} 562$ cells containing about $5 \times 10^{3}$ cells well and cultured in RPMI medium that contains 5, $10,20,50$, and $100 \mu \mathrm{g} \mathrm{mL}^{-1}$ concentrations of active ingredient for 24 hours. Then, I $\mathrm{mg} \mathrm{mL}^{-1}$ MTT (3-(4,5-dimethylthiazol-2-yl)-2,5-diphenyltetrazolium bromide) solution was used to incubation for 4 hours, at $37^{\circ} \mathrm{C}$ in $5 \%$ $\mathrm{CO}_{2}$ humidified incubator. Experiments were studied in three replicates. Finally, the formazan absorbance was immediately measured at $540 \mathrm{~nm}$ using UV-spectrophotometer (Synergy HI, BioTek Instruments, Inc., Vermont, USA).

\section{Apoptosis Assay}

Before the cells were assayed Tali image-based cytometer, cells were stained with Annexin $V$. Annexin- $V / P I$ cells were realized as apoptotic cells (Propidium lodide, Molecular Probes Al0788, and Tali $^{\circledR}$ Apoptosis Kit-Annexin $\vee$ Alexa Fluor ${ }^{\circledR} 488$, respectively). Apoptosis analysis that determined percentages of the life, death, and apoptotic cells was performed as described by Mega-Tiber et al. ${ }^{16}$ and using the Tali ImageBased Cytometer. ${ }^{16}$

\section{Mitochondrial Membrane Potential Assay}

Moreover, apoptosis was also investigated by examining probable changes in the mitochondrial membrane. This assay deterioration in the initial stage of apoptosis was assessed by the change in the permeability of the membrane. To determine probable changes in the mitochondrial membrane using the JC-I (abll3850) probe, cells were washed with PBS, and JC solution was added, finally analyzed using a fluorescent microplate reader filter. The ratio of green fluorescence from low $\Delta \psi \mathrm{M}$ to red fluorescence apoptotic cells from healthy cells with high $\Delta \psi \mathrm{M}$ was calculated using multimode microplate readers with correct filters.

\section{Western Blot Assay}

Cells $\left(5.0 \times 10^{5}\right.$ cells $\left.\mathrm{mL}^{-1}\right)$ were composed with $\mathrm{I} \times$ radioimmune-precipitation assay buffer containing protease inhibitor cocktail (Cat no: II87358000l; Sigma-Aldrich). According to established in the literature, the cells were prepared, loaded on the gel, and transferred onto nitrocellulose-membranes. ${ }^{16,17}$ The membranes were blocked with bovine serum albumin, incubated primary antibodies [caspase-3 (casp-3, 1:200), casp-9 (I:200), bcl-2 (I:200), bax (I:100), and $\beta$-actin (I:200); Santa Cruz, CA, USA] for I hour and incubated with secondary antibody for 12 hours. Beta-actin was used as a housekeeping standard. Finally, the membranes were analyzed using a free software program (Bio-Rad Molecular Analyst, reached from www.totallab.com). Molecular weights were for $\beta$-actin (was used for standardization in all membranes), casp-3, casp-9, bcl-2, and bax; $43,20,46,26$, and $23 \mathrm{kDa}$, respectively.

\section{Data Analysis}

For statistical analysis, GraphPad software (Prism 3.0; GraphPad Software, San Diego, CA, USA) was used. All data were expressed means \pm standard error. The groups of data were analyzed by one-way analysis of variance followed by Bonferroni multiple comparison post hoc tests. $P$ values less than .05 were considered as a statistically significant difference. 


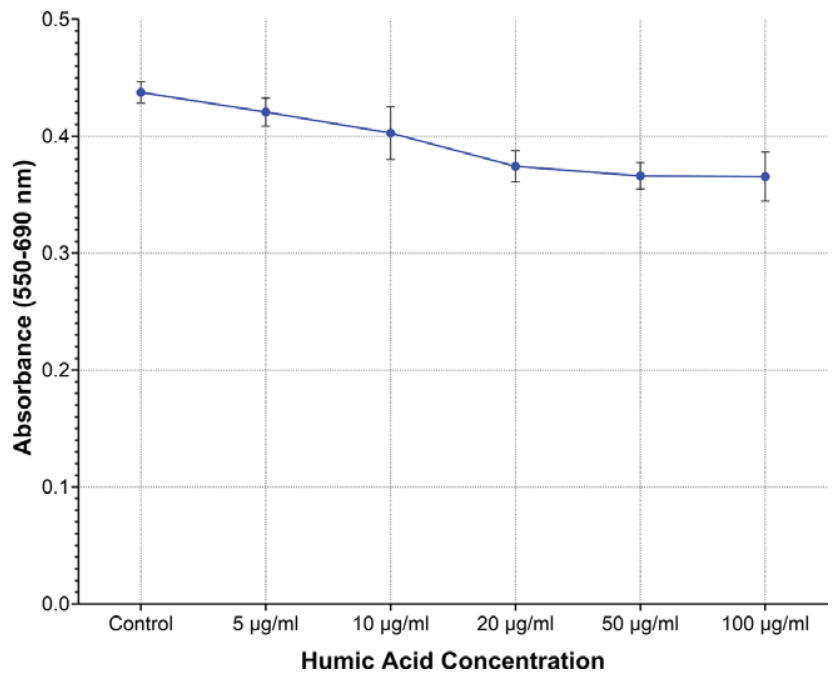

Figure I. The evaluation of the antiproliferative effects of humic acid using the MTT assay at 24 hours in K562 cells ( $n=3$, triplicate)

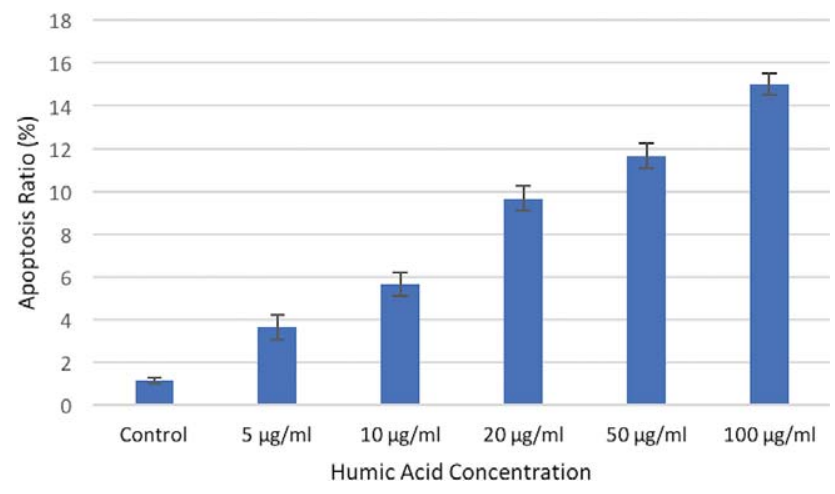

Figure 2. Apoptotic cells were evaluated using the Tali apoptosis kit in $K 562$ cell lines $(n=3)$

\section{RESULTS}

\section{The Cytotoxic Effect of HA on K562 Cells}

Cell proliferation and decreased viability are inhibited by 24hour treatment of $\mathrm{K} 562$ cells with HA. MTT assay was used to determine the cytotoxic effect. Also, cell viabilities were handled after trypan blue staining using a TALI image-based cytometer. After 24 hours of incubation, the treatment of K562 cells with HA was determined by the MTT method, in which the viability of the cells was dose-dependent and the cell proliferation was suppressed (Figure I). Cell proliferation was inhibited by treatment of K562 cells with HA for 24 hours, in particular, it was found that cell proliferation $25 \%$ decreased in $100 \mu \mathrm{g} \mathrm{mL}^{-1}$ of HA (Figure 2).

\section{The Evaluation of Apoptosis and Membrane Potential Assay}

When quantifying annexin $\mathrm{V} / \mathrm{PI}$ staining, the number of apoptotic cells at $100 \mu \mathrm{g} \mathrm{mL}^{-1}$ a dosage of HA was found to be $10 \%$ of the total cell population. It was reached to $15 \%$ at the max concentration of $\mathrm{HA}\left(100 \mu \mathrm{g} \mathrm{mL}{ }^{-1}\right)$. When analyzed with JC-I assay, the obtained apoptotic cell values are the same with a $16 \%$ decrease in cell proliferation (Figure 3).

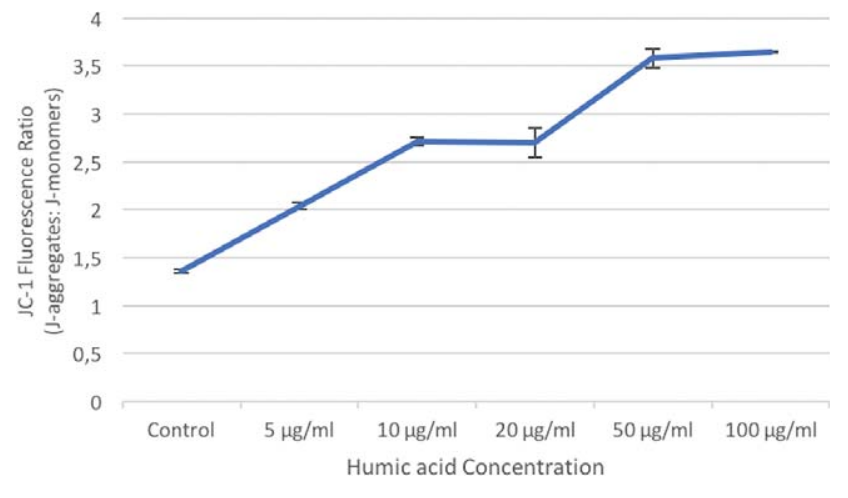

Figure 3. Mitochondrial membrane potential was evaluated using $J C-I$ dye $(n=3)$

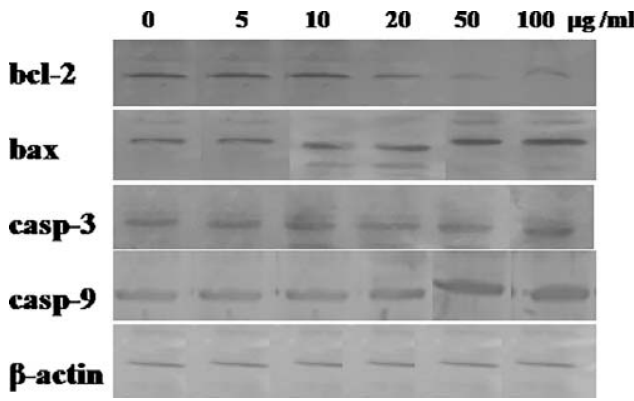

Figure 4. Representative images of western blotting experiments used to determine bcl-2 ( $\cong 26 \mathrm{kDa})$, bax $(\cong 23 \mathrm{kDa})$, casp-3 $(\cong 20$ $\mathrm{kDa})$, casp-9 $(\cong 46 \mathrm{kDa})$, and $\boldsymbol{\beta}$-actin $(\cong 43 \mathrm{kDa})$ expressions' levels ( $n=3$, duplicate)

\section{Immunoblotting Assay}

The bax/bcl-2 ratio is a clear calculation of the permanent apoptosis. Representative images of western blotting experiments used to determine bcl-2/bax ratio and casp-3 and casp9 expression levels are shown in Figure 4. As the amount of HA added increased, there was a minor upregulation in the bax/ bcl-2 ratio, but this was only evident at 50 and $100 \mu \mathrm{g} \mathrm{mL}^{-1}(P<$ .05 , and $P<.001$ for bcl-2; $P<.01$, and $P<.001$ for bax, Table I). At high concentration (50 and $100 \mu \mathrm{g} \mathrm{mL}^{-1}$ ) of HA, casp-9 level increased significantly $(P<.001$ for both concentration), whereas at low concentrations such as $10 \mu \mathrm{g} \mathrm{mL}^{-1}$ and $20 \mu \mathrm{g}$ $\mathrm{mL}^{-1}$, casp-9 level decreased (Table I). Regardless of the low concentration of $\mathrm{HA}$, it was determined that casp-3 was increased only in the highest concentration of HA $\left(100 \mu \mathrm{g} \mathrm{mL}^{-1}\right)$ $(P<.05$, Table I).

\section{DISCUSSION}

Although there is information in the literature on the pharmacological properties of HA and the inhibition of the growth of certain types of cancer cells, such as A549 and human acute promyelocytic leukemia cell line (HL-60), its effect on the growth of different tumor cells, such as K562, and the underlying mechanisms are not fully elucidated. We examined the effect of HA against the K562 cell line and showed that HA inhibited the increase of $\mathrm{K} 562$ cells at concentrations greater than $20 \mu \mathrm{g} \mathrm{mL}{ }^{-1}$. After 24 hours of treatment, $100 \mu \mathrm{g} \mathrm{mL}{ }^{-1}$ a dosage of $\mathrm{HA}$ to $\mathrm{K} 562$ cells was $21 \mu \mathrm{g} \mathrm{mL}^{-1}$. This result shows 


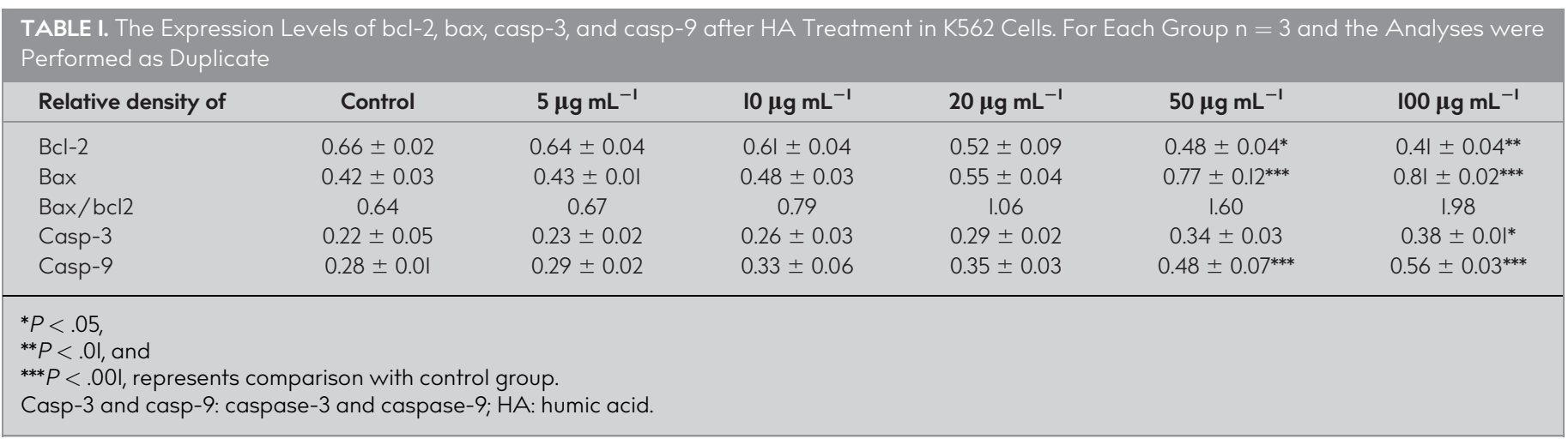

that HA significantly inhibits the proliferation of K562 cells in a dose-dependent manner. Moreover, our study showed that 100 $\mu \mathrm{g} \mathrm{m}^{-1} \mathrm{HA}$ induces apoptosis in $\mathrm{K} 562$ cells by increasing the expressions of proapoptotic proteins at 24 hours. Apoptosis research is important both in explaining cancer development and in developing anticancer therapies. The data obtained from this study suggest that the inhibitory effect of HA on the $\mathrm{K} 562$ cell line may be due to the induction of apoptosis.

The molecular structure of HA with the current study was measured apoptosis-related proprotein and antiapoptotic expression levels in HA-treated K562 cells. We determined the expression levels of bax/bcl-2 ratio after HA treatment in K562 cells. Bax $/ \mathrm{bcl}-2$ ratios were found 0.64 (control), 0.67 (5 $\mu \mathrm{g}$ $\left.\mathrm{mL}^{-1}\right), 0.79\left(10 \mu \mathrm{g} \mathrm{mL}^{-1}\right), 1.06\left(20 \mu \mathrm{g} \mathrm{mL}^{-1}\right), 1.60\left(50 \mu \mathrm{g} \mathrm{mL}^{-1}\right)$, I.98 $\left(\mathrm{I00} \mu \mathrm{g} \mathrm{mL}^{-1}\right.$ ), respectively (Table I). BCL-2 gene family proteins play a role in the regulation of apoptosis. ${ }^{18} \mathrm{BCL}-2$ proteins can make cancer cells resistant to some chemotherapeutic agents. Therefore, BCL-2 related antiapoptotic proteins are important targets in the development of new anticancer agents. ${ }^{19}$ BAX is proapoptotic protein. BAX protein enables the release of apoptogenic factors such as cytochrome $c$, activation of the caspase cascade. $^{20}$

Bax protein's role in apoptosis is the opposite, while bcl-2 protein levels play a role in apoptosis suppression. Our objective in evaluating the bcl-2/bax ratio and casp-3 and casp-9 levels was to assess whether the apoptotic effect of HA was inducing or inhibiting in various concentrations on the K562 cell line. In our results, it was determined that at the 50 and $100 \mu \mathrm{g} \mathrm{mL}^{-1}$ concentrations, the bcl-2 expression level decreased and the increase in the bax expression at the same high concentrations caused a increase in the bax/bcl-2 ratio. Moreover, the results of our study showed that both casp-3 and casp-9 expressions increased in the treatment of $100 \mu \mathrm{g} \mathrm{mL}^{-1} \mathrm{HA}$. Raisova et al. ${ }^{2 l}$ evaluated the change in bcl-2 and bax ratio and emphasized that the decrease in bcl-2/bax ratio is important for apoptosis. There are a large number of studies showing that a wide diversity of chemotherapeutic agents cause apoptosis, an active cell death pattern. ${ }^{2}$ Although there are many in vitro or in vivo studies of HA related to different cancer cells in the literature, its relation with cancer remains unclear. HL-60 cell line treatment using diverse chemotherapeutics is reported to be accompanied by increased cytosolic translocation of cytochrome-c and activation of casp-3. Incubation of HL-60 cells with HA significantly increased bax protein levels. However, the level of bcl-2 is not changed. This result suggests that reducing the level of bcl-2/bax may cause apoptosis. HA $\left(100 \mu \mathrm{g} \mathrm{mL}^{-1}\right)$ ) induction into HL-60 cells resulted in an increase in casp-3 activity from 4 hours to 24 hours. $^{2}$ Similar to the results in the literature, our results suggest that HA has an apoptotic effect on K562 cell lines. Additionally, we investigated the activity of caspase-9; $\mathrm{HA}$ concentrations of 50 and $100 \mu \mathrm{g} \mathrm{mL}^{-1}$ important increases were analyzed.

The in vitro study results of A549 (adenocarcinoma human alveolar basal epithelial cells) and SiHA cells (human cervical cancer cells) are showed that low-dose HA increases the progression of the lung cancer cells. ${ }^{22,23}$ Another high-dose HA research was documented to induce apoptosis via death receptor activation, mitochondrial and endoplasmic reticulum stress signaling cascades. ${ }^{24}$ Also, HA has been shown to produce reactive oxygen species and leads to the depletion of glutathione. $^{25}$

In the literature, HA has been reported to induce oxidative damage, growth retardation, and cell death in human primary fibroblasts. The administration of a single dose of HA $100 \mathrm{mg}$ $\mathrm{kg}^{-1}$ bw by gastric intubations to mice has been reported to result in abnormalities in the structure of induction in intestinal cells. It is reported that HA induces apoptosis in HL-60 and post-initiated mouse epidermal cells. ${ }^{26}$ Similarly, our study results showed that a high concentration of HA contributed to apoptosis of the $\mathrm{K} 562$ cells via decreased bcl-2/bax ratio and increased casp-3 and casp-9 levels.

These findings showed that HA effectively inhibited the proliferation of the $\mathrm{K} 562$ cell line and indicated that apoptosis could be induced by a decrease of the bcl-2/bax ratio and upregulation of casp-3 and casp-9. The results of this study indicate that in the prevention and treatment of $\mathrm{CML}, \mathrm{HA}$ may be a potential for future drug development.

Including the use of humic substances as homeopathic or nutritional supplements, the use as an anticancer agent can be beneficial in the treatment of patients with leukemia.

\section{Ethics Committee Approval: N/A}

Informed Consent: N/A

Peer-review: Externally peer-reviewed.

Author Contributions: Concept - A.A., P.M.T; Design - A.A., P.M.T.; Supervision - A.A., P.M.T; Resource - A.A., P.M.T; Materials - A.A., P.M.T.; Data Collection and/or Processing - A.A., P.M.T.; Analysis 
and/or Interpretation - A.A., P.M.T., T.B.O., M.K.; Literature Search A.A.,P.M.T.,T.B.O.; Writing - A.A., P.M.T., T.B.O., M.K.; Critical Reviews A.A., P.M.T

Conflict of Interest: The authors have no conflicts of interest to declare.

Financial Disclosure: This study was supported by The Experimental Health Sciences Research Centre [grant number SAG-2016-018].

\section{REFERENCES}

I. Hartenstein R. Sludge decomposition and stabilization. Science. 1981;212(4496):743-749. [CrossRef]

2. Yang HL, Hseu YC, Hseu YT, Lu FJ, Lin E, Lai JS. Humic acid induces apoptosis in human premyelocytic leukemia HL-60 cells. Life Sci. 2004;75(I5):|817-183|. [CrossRef]

3. Klöcking R, Helbig B. Medical Aspect and Applications of Humic Substances. Weinheim: Wiley-VCH, 2005:3-16.

4. Kodama H, DENSO. Antitumor effect of humus extract on murine transplantable LI2I0 leukemia. J Vet Med Sci. 2007;69(I0):1069-I07I. [CrossRef]

5. Jooné GK, van Rensburg CEJ. An in vitro investigation of the antiinflammatory properties of potassium humate. Inflammation. 2004;28:169-174. [CrossRef]

6. Guan J, Yang H. Medical value of humic acids. Zhong Yao Cai. 1999;22:430-431. [CrossRef]

7. Vysokogorskii VE, Nozdrunova AA, Plaksin GV, Krivonos Ol, Mkrtchan OZ, Petrosyan LY. Antioxidant activity of liquid products of heat-treated sapropels. Pharm Chem J. 2009;43:191-194. [CrossRef]

8. Klöcking R, Helbig B. Medical aspects and applications of humic substances. In Hofrichter M, Steinbuchel A (eds.): Biopolymers, Vol. I: Lignin, Humic Substances and Coal. Weinheim: Wiley-VCH, 2001:379-392

9. Van Rensburg CEJ, Badenhorst BE, Gandy JJ, Snyman JR. Potassium humate reduces inflammation and clinically improves the outcomes of patients with osteoarthritis of the knee. Conference Proceedings of the International Conference on Drug Discovery and Therapy. Open Conf Proc J. 2010;1:69-74. [CrossRef]

10. Van Rensburg CEJ. The antiinflammatory properties of humic substances: A mini review. Phytother Res. 2015;29:791-795. [CrossRef]

II. Leitner A. Current treatment concepts of CML. Curr Cancer Drug Targets. 20II;II(I):31-43. [CrossRef]

12. Shanmuganathan N, Hiwase DK, Ross DM. Treatment of chronic myeloid leukemia: Assessing risk, monitoring response, and optimizing outcome. Leuk Lymphoma. 2017;58(I2):2799-28I0. [CrossRef]
13. Zhang G, Li M, Han S, et al. Induction of human chronic myeloid leukemia K562 cell apoptosis by virosecurinine and its molecular mechanism. Mol Med Rep. 2014;I0(5):2365-237l. [CrossRef]

14. Galluzzi L, Vitale I, Aaronson SA, et al. Molecular mechanisms of cell death: Recommendations of the nomenclature committee on cell death 2018. Cell Death Differ. 2018;25:486-54I. [CrossRef]

15. Schnitzers MT. In Page AL (ed.): Part 2. Chemical and Microbiological Properties. New York, NY: Academic Press, 1982:581-594.

16. Mega-Tiber P, Kocyigit-Sevinc S, Kilinc O, Orun O. Biological effects of whole Z. officinale extract on chronic myeloid leukemia cell line K562. Gene. 2019;692:217-222. [CrossRef]

17. Kim HG, Oh HJ, Ko JH, et al. Lanceoleins $A-G$, hydroxychalcones, from the flowers of Coreopsis lanceolata and their chemopreventive effects against human colon cancer cells. Bio Org. 2019;85:27428I. [CrossRef]

18. Fulda S. Tumor resistance to apoptosis. Int $J$ Cancer. 2009;124(3):5II-5I5. [CrossRef]

19. Azmi AS, Wang Z, Philip PA, Mohammad RM, Sarkar FH. Emerging Bcl-2 inhibitors for the treatment of cancer. Expert Opin Emerg Drugs. 20ll;16(I):59-70. [CrossRef]

20. Tzifi F, Economopoulou C, Gourgiotis D, Ardavanis A, Papageorgiou $\mathrm{S}$, Scorilas $\mathrm{A}$. The role of BCL2 family of apoptosis regulator proteins in acute and chronic leukemias. Adv Hematol. 2012;2012:524308. [CrossRef]

21. Raisova M, Hossini AM, Eberle J, et al. The Bax/Bcl-2 ratio determines the susceptibility of human melanoma cells to CD95/Fasmediated apoptosis. Invest Dermatol. 2001;II7(2):333-340. [CrossRef]

22. Lee WJ, Lu FJ, Wang SF, Chen YR, Tseng TH. In vitro enhancement effect of humic acid on the progression of lung cancer cells. Chem Biol Interact. 2009;18I(3):463-47I. [CrossRef]

23. Tsai ML, Yen CC, Lu FJ, Ting HJ, Chang HR. Environmentally relevant concentration of arsenic trioxide and humic acid promoted tumor progression of human cervical cancer cells: in vivo and in vitro studies. Environ Toxicol. 2016;3I(9):II2I-II32. [CrossRef]

24. Yang HL, Huang PJ, Chen SC, et al. Induction of macrophage cellcycle arrest and apoptosis by humic acid. Environ Mol Mutagen. 2014;55(9):74l-750. [CrossRef]

25. Yen CC, Lu FJ, Huang CF, Chen WK, Liu SH, Lin-Shiau SY. The diabetogenic effects of the combination of humic acid and arsenic: In Vitro and in vivo studies. Toxicol Lett. 2007;172(3):9lel05. [CrossRef]

26. Lu FJ, Tseng TH, Lee WJ, et al. Promoting neoplastic transformation of humic acid in mouse epidermal JB6 Cl4l cells. Chem Biol Interact. 2006;162(3):249-258. [CrossRef] 